\title{
A Web-based Blended Learning Environment for Programming Languages: Students' Opinions ${ }^{*}$
}

\author{
Mustafa Yağci \\ Correspondence: Mustafa Yağci, Ahi Evran University, Faculty of Education, 40100 Kirsehir, Turkey.
}

Received: January 3, 2017

doi:10.11114/jets.v5i3.2118

\author{
Accepted: February 7, $2017 \quad$ Online Published: February 26, 2017 \\ URL: https://doi.org/10.11114/jets.v5i3.2118
}

\begin{abstract}
A learning environment which increases the desire and efforts of students to attain learning goals leads to greater motivation and success. This study examines the negative and positive opinions of students regarding the effectiveness of the learning process and students' success in a computer programming course in which face-to-face and web-based e-learning methods were blended. The study, for which the case study method is used, was carried out over a 12 week period with the participation of 44 students. A data collection tool consisting of open-ended questions was applied to the participants at the end of the process. The replies given by the participants to the data collection tool were analyzed using qualitative analysis techniques. At the end of the research, the evaluation and satisfaction scores of the students regarding the web-based blended learning environment were found to be positive to a high degree. The positive opinions of the students were focused particularly around four themes, namely "facilitating learning through the learning environment"; "providing interaction opportunities"; "encouraging research", "video support for the course". Negative opinions were gathered around the themes of "lack of sufficient teaching time", "experiencing technical failures", "course badly scheduled" and "comprehensiveness of the course content".
\end{abstract}

Keywords: blended learning; students' opinions; programming languages; web-based learning

\section{Introduction}

Programming languages courses are among the courses which are hardest for students to understand. Many concepts remain intangible for the students and they have difficulty in putting the information they learn to use (Ersoy, Madran \& Gülbahar, 2006). Beginners in programming have low levels of self-efficacy (Altun \& Mazman, 2012). This situation causes the students to develop a negative attitude towards programming. Studies have been emphasizing the use of blended learning environments supported by e-learning tools to provide efficient and productive learning within this framework (Cheng \& Chau, 2015; Brew, 2008; Law, Lee \& Yu, 2010; Uluyol \& Karadeniz, 2009).

The blended learning environment may be identified as integrating electronic or distance learning with face-to-face learning, integrating different learning concepts, methods and techniques and supporting the learning process in class with various online technologies (Uluyol \& Karadeniz, 2009). In other words, blended learning is the use of different information transfer methods within a learning environment and in a mass form (Sloman, 2003). The powerful aspects of online education may be related to the powerful aspects of face-to-face education in blended learning. Therefore, the purpose of the blended learning is to find the balance between online access to information and face-to-face interaction (Osguthorpe \& Graham, 2003). Valiathan (2002) identifies the purpose of blended learning as developing the skills of students with regard to their thinking, their attitudes and their decision-making. Blended learning, which must be considered as a teaching design approach, is a process that needs to be planned strategically in order to be implemented in an educational institution, whether as a learning program or in course form (Mortera-Gutierrez, 2006).

There are many advantages to blended learning. The flexibility in the environment and time, being able to share learning resources from and in an online environment, and the interaction of students both in the class and the online environments are among these advantages. There are different methods for the planning and implementation of blended learning (Oliver $\&$ Trigwell, 2005). Valiathan (2002) suiggest that planning blended learning may be performed in accordance with three different purposes, that is, developing the students' skills, developing their attitudes, and developing decision-making

\footnotetext{
*This study was presented in III. International Dynamic, Explorative and Active Learning (IDEAL) Conference in Samsun and the abstract of the study was published in the Abstract Proceeding.
} 
skills. There is no single method to be used for implementing blended learning (Oliver \& Trigwell, 2005).

According to Osguthorpe and Graham (2003), the main goals to be considered while designing a blended learning environment are as follows:

1. Pedagogical richness

2. Access to knowledge

3. Social interaction

4. Personal agency/Learner control,

5. Cost effectiveness

6. Ease of revision

When blended learning environments are designed by considering the above mentioned goals, they will be more efficient.

There are many studies in the literature relating to the success of the students and/or their motivation in a blended learning environment (Kablan, Baran, Iş1k, M. Kal \& Hazer, 2013; Brew, 2008; Tsuei, 2011; Geçer \& Dağ, 2012; Uluyol \& Karadeniz, 2009; Yağc1, Sırakaya \& Özüdoğru, 2015). For example, Usta (2007) found that blended learning positively affected the attitude of the students in courses, as well as their academic success and the durability of the learning. It could be "In the study conducted by Sarıtepeci and Y1ld1z (2013) noted that blended learning positively affected the development of students' motivation in classes and their active participation. However, there are not many studies about the students' opinions regarding the learning environment and how a blended learning environment affects the success and attitudes in courses which require problem-solving and high-level thinking skills such as teaching programming languages. This study details and evaluates students' opinions regarding this process in an "Introduction to Programming" course which was taught in a project/video-based blended learning environment supported by e-learning tools.

Project-based learning is a model which organizes learning around projects. According to definitions of project-based learning, the projects are complex tasks which depend on the questions and problems. Project-based learning requires the students to actualize various activities, to make designs, to solve problems and to make decisions. It encourages students to present actual final products or presentations by giving a specific period of time to do this. Project-based learning supports cooperative learning, reflection and projection (Blumenfeld et al., 1991; Harris \& Katz, 2001; McGrath, 2003). The projects allow students to learn through practice. The projects also have the aspect of increasing in-depth learning because the students first gain knowledge of relevant concepts, principles and information while developing a project and then have to present a product by implementing these.

In project-based learning, the teacher has to create opportunities for learning by providing access to information and must create a learning environment that provides students with efficient and effective learning across the whole process. In addition, the teacher has to determine and organize the learning stages and should support and guide students. The teacher must follow the process closely, must assist the students with any related problems and must provide feedback and evaluation together with results (Thomas, 2000). The reasons for selecting project-based teaching in a programming language course are to allow students to experience in-depth learning and to develop their problem-solving skills. Geçer and Dağ (2012) found that project-based learning provided students with lesson attendance and was more successful. Students who have colloborative learning style were successful in project based learning and learning retention of these students were higher than others (Cengizhan, 2007). Moreover, in the blended learning environment, Uluyol and Karadeniz (2009) have reached the conclusion that project-based learning students have achieved in positive direction.

Programming language teaching has positive effects on the development of various skills of elementary and secondary school students such as problem-solving, analytic thinking and cooperative study (Akpinar \& Altun, 2014). The Ministry of National Education in Turkey made coding courses obligatory in 2013. The coding courses for elementary and secondary school students are carried out by Information Technologies (IT) teachers. Therefore, it is important that IT candidate teachers examine the programming process in their undergraduate education.

At the end of the educational process, feedback has to be taken from the students relating to the process, and suggestions need to be made about how to increase the quality of the education. The increase in the usage of internet technologies in educational environments forces instructors to think in a more detailed way about the quality of educational activities (Jara \& Mellar, 2010). Finding out students' opinions regarding blended learning environments is important in terms of designing and implementing a quality learning environment (Žuvić-Butorac, Rončević, Nemčanin \& Nebić, 2011; Yağc1, 2016).

\subsection{Purpose of the Research}

"Programming languages" is one of the most important courses in terms of a subject which requires high-level 
problem-solving skills (Askar \& Davenport 2009; Başer, 2013 and Wu \& Yan, 2009). Programming language teaching requires the student to know the structural specifications of the programming language and to have high-level thinking skills. One of the reasons why students have problems in this course, is that they do not understand concepts related to programming because they are not adequately used in concrete applications. Successful implementation requires the right actualization of all the steps in association with each other, and because of this a student who has problems with any one of them may develop a negative attitude towards these steps. The success and motivation of the students with regard to the course may decrease for this and similar reasons. One of the precautions that may be taken to avoid this kind of negativity is to allow for the active participation of the student in the course, because a student who participates in the learning environment as a whole learns more easily and a large part of what is learned remains permanently (Sönmez, 1997). Therefore, research featuring integral comparisons and systematic methods is needed, and this research should begin from different points of view and submit evidence about the value of blended learning according to different methods (Bliuc, Goodyear \& Ellis, 2007). When all these factors are considered, a web-based learning environment can be designed to contribute to the positive attitude and success of the students. The purpose of this research was to identify students' opinions regarding an "Introduction to Programming" course which was planned and implemented with face-to-face and e-learning methods.

Some of the research questions formulated for this purpose were as follows:

1. What scores do students give in their evaluation of the learning environment?

2. What are the satisfaction levels of the students regarding the learning environment?

3. What are the negative and positive opinions of the students relating to the web-based blended learning environment for the "Introduction to Programming" course?

\section{Methodology}

The case study method, which is one of the qualitative research methods, was used in this study. Case study is a qualitative research approach in which cases and themes are evaluated and the data collection tools (observation, interviews, visual-aural evidence, documents, reports), including multi-sources, and one or more cases, within time-limits set by the researcher, are evaluated in an in-depth form (Creswell, 2007). The case study method has been chosen here for analyzing students' opinions of the web-based learning environment designed to support the "Introduction to Programming" course which the teacher candidates also studied through the traditional face-to-face teaching method.

\subsection{Study Participants}

The participants consisted of 44 students studying Computer Education and Instructional Technology (CEIT) at Ahi Evran University in the 2014-2015 academic year. The 44 students (senior students / candidate teachers) in the study were volunteers out of the total of 52 students who were studying the "Introduction to Programming" course.

\subsection{Planning and Implementation of the Course}

A web-based learning environment was developed where project-based and video-based learning methods were used in addition to face-to-face learning. The presentation of the lesson content and various learning activities were designed to cover a 12-week period aimed at developing the skills and knowledge of the students relating to the "Introduction to Programming" course. For this reason, an effort was made to generate a student-centered learning environment in order to direct the students towards further research. A blog tool which provided an opportunity for interaction between the students and the instructors, and a messaging tool where the instructor and the students could communicate individually with each other, were among the benefits of this environment. 2 or 3 discussion questions relating to the subjects taught in the theoretical course were added to the blog site every week. Within the system, students were able to answer these questions, have discussions with friends and watch videos related to "C\# Programming Language".

The blended learning process, the activities to be carried out, the course program and website were introduced to the students in the first week of the course. The course was carried out in the form of 2 hour lessons/applications while 3 hours of theoretical and project studies also took place to outline the conceptual basis of the course each week during a 12 week period. Interim meetings were held with student groups throughout the semester according to dates factored into the project plan and feedback was given to the students regarding the subjects encountered as required. At the same time, feedback was given during these meetings by determining whether the students were proceeding in accordance with the project plan.

\subsection{Data Collection Tools}

A form consisting of four open-ended questions developed by the researcher was used as the data collection tool. The open-ended questions were able to reflect the points of view of the students in a detailed form which provided the opportunity for participants to answer freely (Brew, 2008). First, similar studies in the literature were analyzed to prepare 
the form. The form subsequently prepared was submitted to four experts in the field. The form, which was then revised in accordance with the opinions of the experts, was decreased to two questions. This form was then given to six students who had previously taken the "Introduction to Programming" course and an adjustment was made to one more question in accordance with their opinions. The questions in the form were prepared in order to collect information related to the sub-problems of the research. The final form, after all adjustments had been made, consisted of the questions below:

1. What score out of five would you give to evaluate the education received on the course (from 1 to 5)? Please express your opinion regarding the negative and positive aspects of the course.

2. What is your satisfaction level with this course out of five (from 1 to 5)? Explain the reasons for your choice.

\subsection{Analysis of the Data}

The forms were given numeric codes from S1 to S44 for analyzing the data. The analysis of the qualitative data obtained in the study was carried out using the content analysis technique. Similar data was gathered around specific concepts and themes in the content analysis and was organized and commented on to enable readers to better understand it. The data collected in the study was examined and codes were given to expressions/opinion which formed significant, integral wholes. The themes were formed by starting from the common specifications between the codes. At the result of the coding, a total of 31 codes were formed, 16 of them related to satisfaction and 15 of them related to the educational evaluation. An expert in the field was asked to determine the distribution of the students' opinions according to the codes and themes and to test its suitability as a result of the content analysis. The intercoders' compliance percentage was actualized by the formula of Miles and Huberman (1994):Compliance Percentage $=\frac{\text { Consensus }}{\text { Consensus }+ \text { Dissensus }} X 100$. The compliance percentage was found to be $78 \%$. At the end of the evaluation, 31 of the 35 codes which had been suggested by the researcher were approved and a consensus was reached in the ratio of $31 / 35=0.89$. In showing the codes and themes which were formed following the analysis of the qualitative data, the tables below were used.

The students were asked to evaluate the education received out of 5 points and to express their satisfaction levels. In the analysis of the quantitative data which were obtained accordingly, descriptive statistics such as average, frequency and percentage were used.

\section{Findings and Comments}

\subsection{What Scores Did the Students Give in Evaluating the Learning Environment?}

The scores given by the students in evaluating the learning environment are shown in Table 1.

Table 1. Student evaluation scores for the learning environment

\begin{tabular}{lll}
\hline Evaluation Score & $\mathrm{f}$ & $\%$ \\
\hline 1 & 1 & 2.27 \\
2 & 3 & 6.82 \\
3 & 12 & 27.27 \\
4 & 20 & 45.45 \\
5 & 8 & 18.18 \\
\hline Total & 44 & 99.99 \\
\hline
\end{tabular}

In Table 1, it can be observed that the evaluation scores given by the majority of the students were $4(45.45 \%)$ and 3 $(27.27 \%)$. While 12 of the 44 students awarded the learning environment 3 points, only 3 of them gave it 2 points and 1 of them gave it 1 point. The average evaluation score given by the students in relation to the learning environment was 3.70. This finding shows that the students found education in programming languages using the project-/video-based blended learning method very positive.

\subsection{How Did the Students Rate Their Satisfaction with the Learning Environment?}

The satisfaction levels of the students regarding the learning environment are shown in Table 2.

Table 2. Student satisfaction scores for the learning environment

\begin{tabular}{lll}
\hline Satisfaction Score & f & $\%$ \\
\hline 1 & 1 & 2.27 \\
2 & 4 & 9.09 \\
3 & 10 & 22.73 \\
4 & 19 & 43.18 \\
5 & 10 & 22.73 \\
\hline Total & 44 & 100 \\
\hline
\end{tabular}

In Table 2, it can be observed that the scores for satisfaction given by the majority of the students were $4(43.18 \%)$ and 3 (22.73\%). While 3 of the 44 students awarded the learning environment 2 points, only 1 of them gave it 1 point. The average satisfaction score of students regarding the learning environment was 3.75. This finding shows that the students found the education in programming languages using the project/video-based blended learning method course highly positive. 


\subsection{What Positive and Negative Opinions Did Students Express Regarding Teaching Using a Web-based Blended Learning Environment in the "Introduction to Programming" Course?}

The positive opinions of the students regarding the learning environment are given in Table 3.

Table 3. Positive opinions of the students

\begin{tabular}{lll}
\hline Positive opinions regarding learning environment & $\mathrm{f}$ & $\%$ \\
\hline It facilitates learning & 12 & 26.67 \\
It provides interaction opportunities & 9 & 20 \\
It encourages research & 4 & 8.89 \\
The course is supported with video materials & 4 & 8.89 \\
The course is supported with project-based materials & 3 & 6.67 \\
It is student-centered & 2 & 4.44 \\
It provides adequate teaching & 2 & 4.44 \\
It is applicable to the course & 2 & 4.44 \\
It improves the quality of the education & 1 & 2.22 \\
It supports academic work & 1 & 2.22 \\
A final product/piece of work is produced & 1 & 2.22 \\
It encourages learning & 1 & 2.22 \\
It supports career development & 1 & 2.22 \\
It gives adequate examples & 1 & 2.22 \\
It helps to pass applied computer exams & 1 & 2.22 \\
\hline Total & 45 &
\end{tabular}

It can be observed that the opinions in Table 3 mostly fall into the categories of "facilitating learning" (26.67\%) and "providing interaction opportunities" (20\%). In addition to this, it is observed that the students find the learning process positive in regard to transferring it into further research (8.89\%), that the course is supported with video materials (8.89\%) and that the course is supported by project work. A student expressed the view that the educational environment provides feedback and encourages research and added that: "We can get help from friends and the instructors if there is something we do not know. We reinforce subject knowledge through the discussion questions." Similarly, another student said, "It is beneficial for us when we are encouraged to do research. When we carry out research by ourselves and seek answers to questions, our mind actually learns more about them. While looking for answers to a question, we might find answers not only for this question but also for other questions." Another student, who found the education environment positive in providing student-centered learning, said, "This course is student-centered enough and completely supports student participation." These findings show that a programming languages education supported with e-learning tools may give better results. It can be observed from these results that teaching the "Introduction to Programming" course with a video-/project-based blended learning method supported with a blog site developed the skills of problem-solving and high-level thinking.

The negative opinions of the students regarding the learning environment are given in Table 4.

Table 4. Negative opinions of the students

\begin{tabular}{lll}
\hline Negative opinions regarding learning environment & $\mathrm{f}$ & $\%$ \\
\hline There is a lack of sufficient teaching time & 23 & 35.94 \\
The course is badly scheduled & 11 & 17.19 \\
There are technical failures & 7 & 10.94 \\
The course content is not comprehensive & 6 & 9.38 \\
The course teaching method is not relevant & 4 & 6.25 \\
The classroom is over-crowded & 2 & 3.13 \\
It requires access to the internet & 2 & 3.13 \\
It is not attractive & 1 & 1.56 \\
It is hard to learn from a video & 1 & 1.56 \\
The system should be changed & 1 & 1.56 \\
The lectures/lecture method are not relevant & 1 & 1.56 \\
The course time period is insufficient & 1 & 1.56 \\
There is concern about grades & 1 & 1.56 \\
The course is ineffective & 1 & 1.56 \\
The course interaction tools have to be regularly followed & 1 & 1.56 \\
There is a heavy work load & 1 & 1.56 \\
\hline Total & 64 & \\
\hline
\end{tabular}

In Table 4, it can be observed that the negative opinions of the students regarding the learning environment fall particularly into the categories of "lack of sufficient applications" (35.94\%), "technical failures" (10.94\%), "comprehensiveness of course content" (9.38\%) and "course badly scheduled" (17.19\%). These findings show that more lesson/teaching time is required in the "Introduction to Programming" course which was taught theoretically for 3 hours and practically for 2 hours. In addition to this, the opinions regarding the comprehensiveness of the content are notable. 
This supports the opinions of the students who stated that 2 hours of practical course were not sufficient. In addition, it can be observed in Table 4 that technical deficiencies in the computer laboratory and teaching the course in afternoon affected the motivation of the students negatively. A student who found the learning environment negative in terms of concern about grades said, "If a grade was not given for this, I would not access this site but I have tried many applications and learned these applications due to my concern about grades." A student explained the problems thus: "I think there are problems in the content of the course topics and problems in the implementation of these topics."

\section{Results and Conclusion}

The findings obtained from this study, which evaluated student opinions relating to a project / video-based blended-learning method supported with a blog site show that the average scores for satisfaction and content evaluation were highly positive. As mentioned before, programming languages require high-level problem solving skills. The participation of the student and the implementation of this kind of course is very important. Thus, it may be said that the project-based and student-centered programming languages course had a positive effect on students' success and sense of motivation according to the research results.

The students suggested that teaching the "Introduction to Programming" course with a web-based learning environment had positive effects in terms of application/activities, evaluation and learning. They said that the course facilitated learning in terms of applications and activities, provided interaction opportunities, encouraged research and was student-centered. This finding shows similarity with the results of experimental studies carried out to determine students' opinions of the blended-learning environment (Çağıltay et al., 2007; Uluyol \& Karadeniz, 2009). For example, in research in which Cheng and Chau (2015) analyzed the relationship between online participation and learning success and satisfaction, they found that the students attained more efficient learning and improved material and relational learning.

The students mostly agreed that the learning environment facilitated learning. This finding shows that supporting the "Introduction to Programming" course requiring high-level thinking skills with e-learning tools such as a blog, has a positive effect on the success and motivation of the students. In addition, such an environment facilitates the student-centered teaching of the programming languages course which is one of the hardest courses for students. Similarly, Shaw (2012) found that student's success and satisfaction is higher in programming languages education supported online. In one of their studies, Geçer and Dağ (2012) found that students have positive opinions about the blended learning environment in terms of application and activities. Similar results have been obtained in other research studies in the literature (Demirci Güler, Kaya \& Uzun, 2014; Geçer \& Dağ, 2012).

Moreover, it can be observed that the students find these environments positive in providing interaction opportunities and in encouraging the research. It is understood that sharing course materials via internet, being able to access material when desired and discussing it through blog tools, facilitate a better understanding of subjects. In addition to this, feedback and monitoring discussion on the blogs positively affects the attitude of the students. Similarly, Chrysafiadi and Virvou (2013) found that the students' performance and attitudes regarding the course are higher in a smart e-learning environment. Deperlioğlu and Köse (2010) conclude that students find the blended learning environment positive with regard to sharing ideas, opinions and comments. As Ersoy, Madran and Gülbahar (2011) state, "Learning programming requires a different structure of thinking. Therefore facilitating learning is only possible when the concepts and processes are embodied and it is student-centered. Similarly, Verdú et al.'s (2012) results show that education management systems like Edujudge facilitate the learning process.

The students found the learning environment and process negative in terms of lack of teaching time, the comprehensiveness of the course content and problems with the course schedule. This finding shows that the students have problems in learning programming languages. Hawi (2010) found that an inadequate implementation of the programming language course, the hardness of the subject and the teaching methods are the reasons for any failures. At this stage, it can be suggested that the number of implementation models should be increased and that the curriculum should be reorganized. In addition, it should be understood that the courses like programming languages, which are hard to understand, should be taught during the first hours of the day.

When the students' opinions mentioned above are considered generally, it can be seen that the majority of the students had positive opinions about the blended learning environment. Accordingly, suggestions and encouragement may be given to instructors about how to generalize other courses usually taught in traditional environments into this kind of environment. As mentioned in the literature, it is observed in this study that blended learning is a process which must be strategically planned. The following suggestions may be applied for developing and examining the programming process.

The opinions of the students regarding their credits/grades for using e-learning tools in the course, as well as the environment, the independent use of time and the opportunites for communication while learing which these tools provide, draw attention in this study. In today's information society, when the need to possess information and communication technology skills and the advantages of a blended learning approach are considered, further research could be performed 
on how using different information and communication technologies in blended learning environments affects the efficient learning of these technologies.

This study is a qualitative study which examined students' opinions regarding a blended learning environment. In this respect, it may be said that the study is limited. Future studies could be performed to monitor qualitative and quantitative aspects of different and larger groups using blended learning environments. Studies which evaluate the success and motivation of the students by considering individual differences and interaction types as independent variables would make a contribution to the field. Lastly, it is suggested that the relationship between the academic success and opinions of students with previous knowledge of, interest in and skills in using such environments be investigated.

\section{References}

Akpınar, Y., \& Altun, A. (2014). The need for programming education in information society schools. Elementary Education Online, 13(1).1-4

Altun, A., \& Mazman, S. G. (2012). Validity and Reliability Study of Turkish Form of Perception of Self-Sufficiency Perception Related to Programming. Journal of Measurement and Evaluation in Education and Psychology, 3(2), 297-308.

Askar, P., \& Davenport, D. (2009). An Investigation Of Factors Related To Self-Efficacy For Java Programming Among Engineering Students. The Turkish Online Journal of Educational Technology, 8(1).

Başer, M. (2013). Developing Attitude Scale Toward Computer Programming. The Journal of Academic Social Science Studies, 6(6), 199-215. https://doi.org/10.9761/JASSS1702

Bliuc, A., Goodyear, P., \& Ellis, R. A. (2007). Research focus and methodological choices in studies into students' experiences of blended learning in higher education. Internet and Higher Education, 10, 231-244. https://doi.org/10.1016/j.iheduc.2007.08.001

Blumenfeld, P. C., Soloway, E., Marx, R., Krajcik, J., Guzdial, M., \& Palincsar, A. (1991).Motivating project-based learning: Sustaining the doing, supporting the learning. Educational Psychologist, 26(3\&4), 369-398. https://doi.org/10.1080/00461520.1991.9653139

Brew, L. S. (2008). The role of student feedback in evaluating and revising a blended learning course. Internet and Higher Education, 11(2), 98-105. https://doi.org/10.1016/j.iheduc.2008.06.002

Çağıltay, K., Yıldırım, S., Aslan, İ., Gök, A., Gürel, G., Karakuş, T., ... Yıldız, İ. (2007). Habits and expectations for the use of instructional technologies in the university: a descriptive study. Academic Computing Conference'07-IX, Dumlupınar University, Kütahya.

Cengizhan, S. (2007). The Effects of Project Based and Computer Assisted Instructional Designs On Those Students' Who Have Depended, Independed and Cooperative Learning Styles, Academic Achievement And Learning Retentio. The Journal of Turkish Educational Sciences, 5(3), 377-401.

Cheng, G., \& Chau, J. (2015). Exploring the relationships between learning styles, online participation, learning achievement and course satisfaction: An empirical study of a blended learning course. British Journal of Educational Technology. https://doi.org/10.1111/bjet.12243

Chrysafiadi, K., \& Virvou, M. (2013). PeRSIVA: An empirical evaluation method of a student model of an intelligent e-learning environment for computer programming. Computers \& Education, 68, 322-333. https://doi.org/10.1016/j.compedu.2013.05.020

Creswell, J. W. (2007). Qualitative inquiry and research design: Choosing among five traditions (2nd ed.). London: Sage.

Demirci, G. M. P., Kaya, S., \& Uzun, A. (2014). Science Teachers' Views on the Internet Use in Education (The Case of Kırşehir). Journal of Kırşehir Education Faculty, 15(1), 263-280.

Deperlioğlu, Ö., \& Köse, U. (2010). Effects of Web 2.0 Technologies on the Education and An Example Learning Experience. 2010 Academic Computing Conference, 166-172.

Geçer, A., \& Dağ, F. (2012). A Blended Learning Experience. Educational Sciences: Theory \& Practice, 12 (1), $425-442$.

Harris, A., \& Katz, L. G. (2001). Young investigators: The Project approach in the early years. New York: Teachers College Press.

Hawi, N. (2010). Causal attributions of success and failure made by undergraduate students in an introductory-level computer programming course. Computers \& Education, 54(4), 1127-1136. https://doi.org/10.1016/j.compedu.2009.10.020

Jara, M., \& Mellar, H. (2010). Quality enhancement for e-learning courses: The role of student feedback. Computers \& Education, 54(3), 709-714. https://doi.org/10.1016/j.compedu.2009.10.016

Kablan, Z., Baran, T., Işık, Ç., M. Kal, F., \& Hazer, Ö. (2013). Comparison of PowerPoint and Concrete Teaching 
Materials in terms of Learning Efficiency. Education and Science, 38(170), 206-222.

Law, K. M. Y., Lee, V. C. S., \& Yu, Y. T. (2010). Learning motivation in e-learning facilitated computer programming courses. Computers \& Education, 55(1), 218-228. https://doi.org/10.1016/j.compedu.2010.01.007

McGrath, D. (2003). Launching a Project Based Learning, Learning \& Leading with Technology. Artifacts and Understanding, 30(4), 36-39.

Miles, M. B., \& Huberman, A. M. (1994). Qualitative Data Analysis: An Expanded Sourcebook. London: Sage.

Mortera-Gutiérrez, F. (2006). Faculty best practices using blended learning in e-learning and face-to-face instruction. International Journal on E-learning, ProQuest Education Journals, 5 (3), 313-337.

Muğla, Ersoy, H., Madran, R. O., \& Gülbahar, Y. (2011). A Model Proposed for Teaching Programming Languages: Robotic Programming. XIII. Academic Computing Conference, 731-736, Malatya.

Oliver, M., \& Trigwell, K. (2005). Can “blended learning” be re-deemed? E-learning, 2(1), 17-26. https://doi.org/10.2304/elea.2005.2.1.2

Osguthorpe, R. T., \& Graham, C. R. (2003). Blended Learning Environments Definitions and Directions. The Quarterly Review of Distance Education, 4(3), 227-233.

Saritepeci, M., \& Y1ldı, H. (2014). The Effect of Blended Learning Environments on Students' Engagement to Course and Motivation toward the Course. Journal of Kirşehir Education Faculty, 35(1), 115-129.

Shaw, R. S. (2012). A study of the relationships among learning styles, participation types, and performance in programming language learning supported by online forums. Computers \& Education, 58(1), 111-120. https://doi.org/10.1016/j.compedu.2011.08.013

Sloman, M. (2003). Training in the age of the learner. London, UK : Chartered Institute of Personel and Development.

Sönmez, V. (1997). Social Studies Instruction and Teacher's Guide. Ankara: Anı Publish.

Thomas, J. W. (2000). A Review of Research on Project-Based Learning. San Rafael, CA: Autodesk Foundation.

Tsuei, M. (2011). Development of a peer-assisted learning strategy in computer-supported collaborative learning environments for elementary school students. British Journal of Educational Technology, 42(2), 214-232. https://doi.org/10.1111/j.1467-8535.2009.01006.x

Uluyol, Ç., \& Karadeniz, Ş. (2009). An Example on Blended Learning Environment: Student Achievement and Perceptions. Yüzüncü Yll Üniversity Journal of Education, 4(1), 60-84.

Usta, E. (2007). The Effects Of Blended Learning And Online Learning On Academic Achievement And Learner Satisfaction. Unpublished Doctoral Dissertation, Gazi University, Institute of Educational Sciences, Ankara.

Valiathan, P. (2002). Blended learning models. Learning circuits, 3(8), 50-59.

Verdú, E., Regueras, L. M., Verdú, M. J., Leal, J. P., de Castro, J. P., \& Queirós, R. (2012). A distributed system for learning programming on-line. Computers \& Education, 58(1), 1-10. https://doi.org/10.1016/j.compedu.2011.08.015

Wu, M., \& Yan, H. (2009). Simulation in software engineering with system dynamics: A case study. Journal of Software, 4(10), 1127-1135. https://doi.org/10.4304/jsw.4.10.1127-1135

Yağc1, M. (2016). Effect of attitudes of information technologies (IT) preservice teachers and computer programming (CP) students toward programming on their perception regarding their self-sufficiency for programming. International Journal of Human Sciences, 13(1), 1418-1432. https://doi.org/10.14687/ijhs.v13i1.3502

Yağcı, M., Sirakaya, D. A., \& Özüdoğru, G. (2015). The Investigation of Attitude and Readiness of Information and Communication Technologies Pre-service Teachers toward Web Based Learning. Procedia - Social and Behavioral Sciences, 174, 1099-1106. https://doi.org/10.1016/j.sbspro.2015.01.800

Žuvić-Butorac, M., Rončević, N., Nemčanin, D., \& Nebić, Z. (2011). Blended e-learning in higher education: Research on students' perspective. Issues in Informing Science and Information Technology, (8), 409-429.

\section{Copyrights}

Copyright for this article is retained by the author(s), with first publication rights granted to the journal.

This is an open-access article distributed under the terms and conditions of the Creative Commons Attribution license which permits unrestricted use, distribution, and reproduction in any medium, provided the original work is properly cited. 